\title{
"Anatomy and Imaging": 10 Years of Experience with an Interdisciplinary Teaching Project in Preclinical Medical Education - From an Elective to a Curricular Course
}

\section{„Anatomie und Bildgebung": 10 Jahre Erfahrung mit einem interdisziplinären Lehrprojekt im vorklinischen Medizinstudium - vom Wahlkurs zum curricularen Kurs}

Authors

Affiliations
A. Schober ${ }^{1}$, C. C. Pieper ${ }^{1,2}$, R. Schmidt ${ }^{3}$, W. Wittkowski ${ }^{1}$

Institute of Anatomy and Molecular Neurobiology, University of Muenster, Germany

Department of Radiology, University of Bonn, Germany

Department of Clinical Radiology, University of Muenster, Germany
Key words

- education

- anatomy

- teaching of anatomy

- radiologic anatomy

- preclinical curriculum

received 20.5.2013

accepted $\quad 30.8 .2013$

Bibliography

Dol http://dx.doi.org/

10.1055/s-0033-1355567

Published online: 14.10.2013

Fortschr Röntgenstr 2014; 186: 458-465 @ Georg Thieme

Verlag KG Stuttgart - New York . ISSN 1438-9029

\section{Correspondence}

Anna Schober, M. D.

Institute of Anatomy and

Molecular Neurobiology,

University of Muenster

Vesaliusweg 2-4

48149 Münster

Tel.: ++49/2 51/8350206

anna.schober@ukmuenster.de

\section{Abstract}

Purpose: Presentation of an interdisciplinary, interactive, tutor-based preclinical teaching project called "Anatomy and Imaging".

Materials and Methods: Experience report, analysis of evaluation results and selective literature review.

Results: From 2001 to 2012, 618 students took the basic course (4 periods per week throughout the semester) and 316 took the advanced course ( 2 periods per week). We reviewed 557 (return rate $90.1 \%$ ) and 292 (92.4\%) completed evaluation forms of the basic and the advanced course. Results showed overall high satisfaction with the courses (1.33 and 1.56, respectively, on a 5-point Likert scale). The recognizability of the relevance of the course content for medical training, the promotion of the interest in medicine and the quality of the student tutors were evaluated especially positively.

Conclusion: The "Anatomy and Imaging" teaching project is a successful concept for integrating medical imaging into the preclinical stage of medical education. The course was offered as part of the curriculum in 2013 for the first time. "Anatomia in mortuis" and "Anatomia in vivo" are not regarded as rivaling entities in the delivery of knowledge, but as complementary methods.

Key points:

- "Anatomy and Imaging" is an interdisciplinary, interactive, tutor-based preclinical teaching project.

- Imaging techniques potentially deliver anatomical knowledge effectively.

- Student tutors enable teaching in small groups (up to 10 participants).

- Since 2013, the former elective has become part of the curriculum.
- The course introduces preclinical students to radiology.

Citation Format:

- Schober A, Pieper CC, Schmidt R et al. "Anatomy and Imaging": 10 Years of Experience with an Interdisciplinary Teaching Project in Preclinical Medical Education - From an Elective to a Curricular Course. Fortschr Röntgenstr 2014; 186: 458-465

\section{Zusammenfassung \\ $\nabla$}

Ziel: Vorstellung des interdisziplinären, interaktiven, tutorengestützten, vorklinischen Lehrprojektes „Anatomie und Bildgebung“.

Material und Methoden: Erfahrungsbericht, Auswertung der Evaluationsergebnisse sowie selektive Literaturrecherche.

Ergebnisse: Zwischen 2001 und 2012 besuchten 618 Studierende den Grundkurs (4 Semesterwochenstunden) und 316 den Aufbaukurs (2 Semesterwochenstunden). Zur Auswertung lagen 557 (Rücklaufquote 90,1\%) bzw. 292 (92,4\%) vollständig ausgefüllte Evaluationsbogen vor. Die Gesamtbewertung der Kurse war gut bis sehr gut (1,33 bzw. 1,56 auf einer 5-stufigen Likert-Skala). Positiv beurteilt wurden insbesondere die Erkennbarkeit der Relevanz der Kursinhalte für die ärztliche Ausbildung, die Förderung des Interesses an der Medizin sowie die Qualität der studentischen Tutoren.

Schlussfolgerung: Das Lehrprojekt „Anatomie und Bildgebung“" stellt ein erfolgreiches Konzept zur Integration bildgebender Verfahren in die Vorklinik dar. Im Jahre 2013 hat der Kurs erstmals im Rahmen der curricularen Lehre stattgefunden. Anatomie „in mortuis“ und Anatomie "in vivo“ werden nicht als konkurrierende, sondern als sich ergänzende Methoden der Wissensvermittlung angesehen. 


\section{Introduction}

Human anatomy is the basis for almost all clinical action. This fact is highlighted by a survey of 318 medical students, $94 \%$ of whom regard the course of gross anatomy as relevant [1]. Specialists before final board examination feel that anatomy is the most important preclinical subject for later work [2].

However, the anatomical knowledge of students entering the clinical stage of medical education is often classified as poor for safe clinical practice. Conventional anatomy courses seem to prepare students inadequately for their clinical tasks [3]. Even students themselves do not feel properly trained $[4,5]$. In an article published in 2012, it was yet again demanded to shift the focus of anatomy teaching onto the anatomy of the living which is often different from the anatomy of corpses [6]. One possibility for this "anatomia in vivo" is medical imaging. Over the last few years these techniques have been gaining an increasingly important status in anatomy teaching [7-9], but until 2006 they comprised a mere $5 \%$ of actual teaching time [10]. However, synergistic effects have been shown to lead to an increased interest in the subject as well as better learning and dissection skills in the long run [11-15]. $80 \%$ of the student body would be happy about the introduction of an imaging course in their anatomical education [16]. Positive experiences have been reported about sonography courses as well [17 - 19]. Combining the traditional dissection course with visual methods seems to be the most effective teaching procedure [19].

The present medical faculty has a 30 -year record of delivering anatomical knowledge by means of the living ( 0 Table 1 ). In 2001, "Anatomy and Imaging" was established as a bridging course between the preclinical and the clinical stage. The purpose of this course is to deepen knowledge within a clinical context and to provide first contact with medical imaging.

We report our experiences and the course evaluations over the last 10 years.

\begin{tabular}{|c|c|}
\hline date & activity \\
\hline $1982-1999$ & $\begin{array}{l}\text { "Anatomy of the Living" and "X-ray Anatomy" seminars as } \\
\text { an accompaniment to the "Gross Anatomy Course" }\end{array}$ \\
\hline 1995 & addition of "Sonographic Anatomy" \\
\hline $1999-2001$ & $\begin{array}{l}\text { complementary course "Anatomy in the Preclinical Prac- } \\
\text { tice" with the following course parts: clinical examination, } \\
\text { X-ray anatomy, sonographic anatomy and clinical evening } \\
\text { events }\end{array}$ \\
\hline 2001 & $\begin{array}{l}\text { authorization of subsidies through the program "Quality } \\
\text { of Education" by the Ministry of Education, Science and } \\
\text { Research; establishment of an integrative course concept } \\
\text { with the founding of the basic and advanced course } \\
\text { "Anatomy and Imaging" }\end{array}$ \\
\hline 2003 & $\begin{array}{l}\text { coming into force of the new Licensing Regulations for Phy- } \\
\text { sicians (Approbationsordnung of } 27 / 6 / 2002 \text { ); recognition } \\
\text { of the course as an "Elective with a Graded Certificate" }\end{array}$ \\
\hline 2012 & $\begin{array}{l}\text { new concept of the course as a day-long block course on } \\
\text { four days of the week }\end{array}$ \\
\hline 2013 & $\begin{array}{l}\text { beginning of the curricular offering of the block course } \\
\text { "Anatomy and Imaging" in the framework of the "Seminars } \\
\text { with Clinical References" according to the Licensing Regu- } \\
\text { lations for Physicians (ÄAppO) }\end{array}$ \\
\hline
\end{tabular}

\section{Materials and Methods}

$\nabla$

The course is organized into a basic and an advanced course, lasting a semester each. The maximum number of participants per semester was limited to 30 students. The course structure and syllabus are shown in $\bullet$ Table 2.

\section{Basic course}

Management of the course came under the responsibility of the Institute of Anatomy. Staff from the Institute of Clinical

Table 2 Structure and content of the basic and advanced course (as in 2012).

\begin{tabular}{|c|c|}
\hline one-year course & lessons, group size, content \\
\hline \multicolumn{2}{|l|}{ part 1: basic course } \\
\hline X-ray and & 12 course entities, 10 participants/group \\
\hline \multirow[t]{12}{*}{ CT-anatomy } & $1 \mathrm{X}$-ray/CT spine \\
\hline & $2 \mathrm{X}$-ray pelvis/hip \\
\hline & $3 \mathrm{X}$-ray hand/elbow \\
\hline & $4 \mathrm{X}$-ray shoulder/skeletal thorax \\
\hline & $5 \mathrm{X}$-ray thorax (lung/pleura) \\
\hline & $6 \mathrm{X}$-ray thorax (heart/big vessels) \\
\hline & 7 CT thorax \\
\hline & $8 \mathrm{X}$-ray abdomen \\
\hline & $9 \mathrm{CT}$ abdomen \\
\hline & 10 CT skull \\
\hline & $11 \mathrm{CT} / \mathrm{MRI}$ brain \\
\hline & 12 Head injury \\
\hline \multirow[t]{5}{*}{ ultrasound anatomy } & 12 course entities, 5 participants/group \\
\hline & 6 hours of sonography of the upper abdomen \\
\hline & 1 hour of sonography of the lower abdomen \\
\hline & 1 hour of sonography of the thyroid gland \\
\hline & 4 practice sessions \\
\hline \multirow[t]{9}{*}{ clinical lectures } & 8 lessons \\
\hline & 1 introduction to radiology \\
\hline & 2 sonographic anatomy I \\
\hline & 3 sonographic anatomy II \\
\hline & 4 hand injuries in sports \\
\hline & 5 spine, imaging and clinical examination \\
\hline & 6 introduction to nuclear medicine \\
\hline & 7 special nuclear medicine heart/brain/PET-CT \\
\hline & 8 intracranial bleeding \\
\hline examination & $\begin{array}{l}\text { written (multiple choice) } \\
\text { practical (objective structured clinical examination) }\end{array}$ \\
\hline \multicolumn{2}{|l|}{$\begin{array}{l}\text { part 2: advanced } \\
\text { course }\end{array}$} \\
\hline sonography & 6 lessons, 10 participants/group \\
\hline 4 topic blocks & 11 lessons, 10 participants/group \\
\hline \multirow[t]{5}{*}{ part a: technique } & systematics of chest X-ray \\
\hline & systematics of skeletal radiology \\
\hline & MRI technique \\
\hline & CT technique \\
\hline & digital subtraction angiography technique \\
\hline \multirow[t]{5}{*}{ part b: applications } & brain hemorrhage \\
\hline & stroke \\
\hline & prevalent pathologies in the X-ray of the chest \\
\hline & musculoskeletal MRI \\
\hline & interventions in radiology \\
\hline \multirow{5}{*}{$\begin{array}{l}\text { part c: synoptic } \\
\text { cases }\end{array}$} & management of trauma \\
\hline & thoracic pain \\
\hline & tumor staging: thorax \\
\hline & tumor staging: skeleton \\
\hline & tumor staging: abdomen \\
\hline \multirow[t]{2}{*}{ part d: lectures } & mammography \\
\hline & pediatric radiology \\
\hline
\end{tabular}


Radiology as well as medical lecturers from other fields were involved in medical lectures.

\section{Participants and entry requirements}

The basic course was aimed at preclinical students upon their completion of the gross anatomy course. On account of the students' keen interest, the passing of an entrance exam was a prerequisite for participation. The top thirty students among approximately sixty applicants were admitted to the course.

\section{Course structure}

Classes on X-ray anatomy, ultrasound and clinical lectures took place weekly for one hour in each subject, either in small groups or in an assembly (total attendance 4 periods per week throughout the semester).

\section{X-ray and CT anatomy}

Initially, an introduction to the systematics of image viewing and analysis was given. Every group study unit (10 students) began with a discussion of a normal X-ray for the purpose of identifying and demonstrating known anatomic structures. Subsequently, two students examined a clinical case. In addition to the X-rays, the anamnesis and cause of referral were made available for this purpose. As a rule, pathologies were chosen in such a way that they could be derived from knowledge of normal anatomy (i.e., distal radial fracture, lobar pneumonia, hemorrhage of the subarachnoid). Following this, one student from each of the teams was required to present the case to the group. Attention was particularly drawn to the observance of systematic image analysis as the core competence to be learned. Every student was required to demonstrate at least one case per lesson.

\section{Ultrasound anatomy}

Sonographic anatomy was instructed in small groups of five students in order to achieve a longer active exercise session for learning practical skills. Firstly, technical fundamentals of sonography were conveyed during two introductory lectures. Secondly, the students examined each other in turn. Specific standard planes, in which anatomical structures were to be identified and indicated, had to be reproduced.

\section{Anatomy of the Living}

Until 2003, "Anatomy of the Living" was a fixed component of the course and was concerned with the anatomical identification of anatomical 'landmarks' on the living. In a second step, fundamental clinical examination methods were conveyed. The students again examined each other in turn. Due to the introduction of a clinical examination course in the preclinical phase in 2003, this part of the course was omitted.

\section{Clinical lectures}

Lectures by experienced clinicians complemented the concept of education to demonstrate the relevance of imaging (० Table 2).

\section{Advanced course}

The advanced course "Anatomy and Imaging" was for students who had successfully completed the basic course. It took place once a week in small groups of ten participants
( 2 periods per week throughout the semester). Management of the course was now under the responsibility of the Department of Clinical Radiology. As in the basic course, the syllabus and the personnel were matched with lecturers from the Institute of Anatomy.

\section{Course structure}

Initially, the students began with a discussion of essential radiological techniques and the consolidation of the systematics of image analysis. For instance, the Seldinger puncture technique could be tried out on a model. Afterwards, clinical cases (e.g. stroke management) were independently processed by the students under the guidance of one of the student tutors. The emphasis was on the systematic image analysis and on the exact anatomical relationships of the results (e.g. the attribution of the ischemic brain area to the supplying artery and the resulting clinical deficits). In addition, true synoptic cases were treated interactively in the course of which the students could selfreliantly collect an anamnesis and clinical data, as well as arrange for various imaging procedures. Also, the justifying medical indication for the examination was retraced (॰ Table 2).

In the sonography course, the previously obtained skills could be intensified on real patients. The patients had already expressed their approval for the examination to be carried out by the students. The focus of the course was again based on a systematic line of action concerning the survey of the case history, as well as the physical and sonographic examination.

\section{Tutors and lecturers}

The periods of study in the basic and advanced courses were given by student tutors from clinical semesters under the supervision of medical lecturers. Prerequisites for becoming a tutor were a successful participation in the course itself in addition to a top mark in the preliminary medical examination. Further conditions were teaching experience as a tutor in the gross anatomy course and completion of a four-week clinical elective in the Department of Clinical Radiology. Before each course session, a preliminary discussion was held between the medical heads of the course and the student tutors. The majority of the tutors were available for several semesters.

\section{Script}

An extensive script covering relevant anatomical and clinical information as well as checklists for systematic reporting were made available in print and/or online for both courses, enabling students to prepare before and after.

\section{Final examination}

The basic and the advanced course each finished with a multiple choice exam, covering the content of every lesson. For the basic course, a practical test in the form of an OSCE (objective structured clinical examination) with stations for $\mathrm{X}$-ray/CT and sonographic anatomy took place. Special attention was given to the observance of systematic reporting and to the correct description of the anatomic structures as well as to an adequate behavior towards the test person. The grading was carried out by the student tutors in accordance with a previously stipulated standardized pattern. 


\begin{tabular}{|c|c|c|c|c|c|}
\hline \multirow{2}{*}{ The course was well organized. } & \multicolumn{3}{|c|}{ fully agree } & \multicolumn{2}{|c|}{ do not agree } \\
\hline & 1 & 2 & 3 & 4 & 5 \\
\hline \multicolumn{6}{|l|}{ comments: } \\
\hline The material was structured clearly. & 1 & 2 & 3 & 4 & 5 \\
\hline \multicolumn{6}{|l|}{ comments: } \\
\hline The selection of topics was good. & 1 & 2 & 3 & 4 & 5 \\
\hline \multicolumn{6}{|l|}{ comments: } \\
\hline The instructors and tutors communicated the material appropriately. & 1 & 2 & 3 & 4 & 5 \\
\hline \multicolumn{6}{|l|}{ comments: } \\
\hline \multicolumn{6}{|l|}{ part 2: Ultrasound anatomy } \\
\hline & \multicolumn{3}{|c|}{ fully agree } & \multicolumn{2}{|c|}{ do not agree } \\
\hline The course was well organized. & 1 & 2 & 3 & 4 & 5 \\
\hline \multicolumn{6}{|l|}{ comments } \\
\hline The material was structured clearly. & 1 & 2 & 3 & 4 & 5 \\
\hline \multicolumn{6}{|l|}{ comments: } \\
\hline The selection of topics was good. & 1 & 2 & 3 & 4 & 5 \\
\hline \multicolumn{6}{|l|}{ comments: } \\
\hline Training time was sufficient. & 1 & 2 & 3 & 4 & 5 \\
\hline \multicolumn{6}{|l|}{ comments: } \\
\hline The instructors and tutors communicated the material appropriately. & 1 & 2 & 3 & 4 & 5 \\
\hline \multicolumn{6}{|l|}{ comments } \\
\hline \multicolumn{6}{|l|}{ part 3: Clinical lectures } \\
\hline & & agree & & & tagree \\
\hline The course was well organized. & 1 & 2 & 3 & 4 & 5 \\
\hline comments & & & & & \\
\hline The selection of topics was good. & 1 & 2 & 3 & 4 & 5 \\
\hline comments & & & & & \\
\hline The instructors and tutors communicated the material appropriately. & 1 & 2 & 3 & 4 & 5 \\
\hline comments & & & & & \\
\hline part 4: "Anatomy and Imaging" in total & & & & & \\
\hline & & agree & & & tagree \\
\hline The choice of media was adequate. & 1 & 2 & 3 & 4 & 5 \\
\hline comments & & & & & \\
\hline The script provided a good working basis. & 1 & 2 & 3 & 4 & 5 \\
\hline comments & & & & & \\
\hline The course contributed to my learning process. & 1 & 2 & 3 & 4 & 5 \\
\hline comments & & & & & \\
\hline Relevance for medical education was evident. & 1 & 2 & 3 & 4 & 5 \\
\hline comments & & & & & \\
\hline The course enhanced my interest in medicine. & 1 & 2 & 3 & 4 & 5 \\
\hline comments & & & & & \\
\hline I am satisfied with the course. & 1 & 2 & 3 & 4 & 5 \\
\hline comments & & & & & \\
\hline Expenditure of time spent was & & tle: & & & \\
\hline comments & & & & & \\
\hline The course level was & & & & & \\
\hline comments & & & & & \\
\hline
\end{tabular}

Table 3 Questions on the evaluation form in the basic course.

\section{Evaluation}

\section{$\nabla$}

Within the framework of the final examinations, the students were required to evaluate each course. The evaluation form had been kept constant over the entire period of the last 10 years ( $\bullet$ Table 3$)$. We used a 5-point Likert scale (1: fully agree, 5: do not agree). After every semester, a discussion about the course evaluation took place between lecturers and tutors for future improvement.

\section{Results}

\section{$\nabla$}

Participants

During the period from 2001 to 2012, 618 students (311 males and 307 females) enrolled in the basic course "Anatomy and Imaging", and 614 (99.4\%) attended the complete course and took the final examination. The majority of the students were in the third preclinical semester when they started the basic course. 316 students (149 males, $167 \mathrm{fe}$ males) attended the subsequent advanced course.

\section{Evaluation results}

Of the 618 participants of the basic course, 557 completed assessment forms were available ( $90 \%$ of the total). Of the 
316 participants of the advanced course, 292 of the assessment forms could be evaluated ( $92 \%$ of the total). The results are displayed in $\bullet$ Fig. $\mathbf{1 - 3}$.

On a 5 -point Likert scale ( 1 = fully agree; $5=$ do not agree), the statement "the relevance for medical education was evi- dent" received the highest rating of 1.17 (basic course) and 1.24 (advanced course). The statement "the script provided a good working base" received the lowest rating (1.53 for the basic course; 2.58 for the advanced course). The quality of the tutors was rated with 1.42 and 1.51 , respectively. The

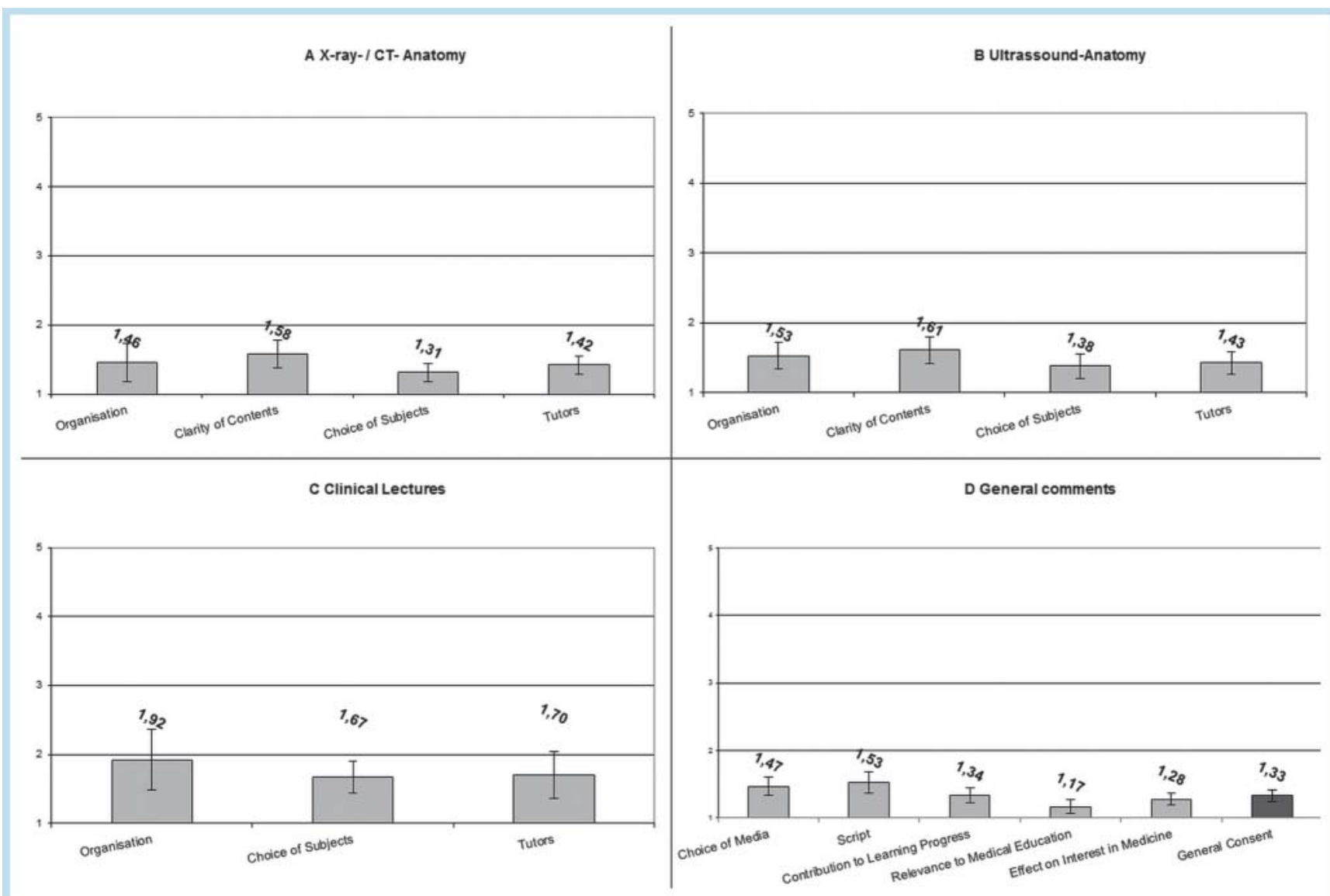

Fig. 1 Evaluation results for basic course for A X-ray and CT-Ultrasound anatomy, B sonographic anatomy, C clinical lectures, D total assessment 5-point Likert scale (1: fully agree, 5 : do not agree).

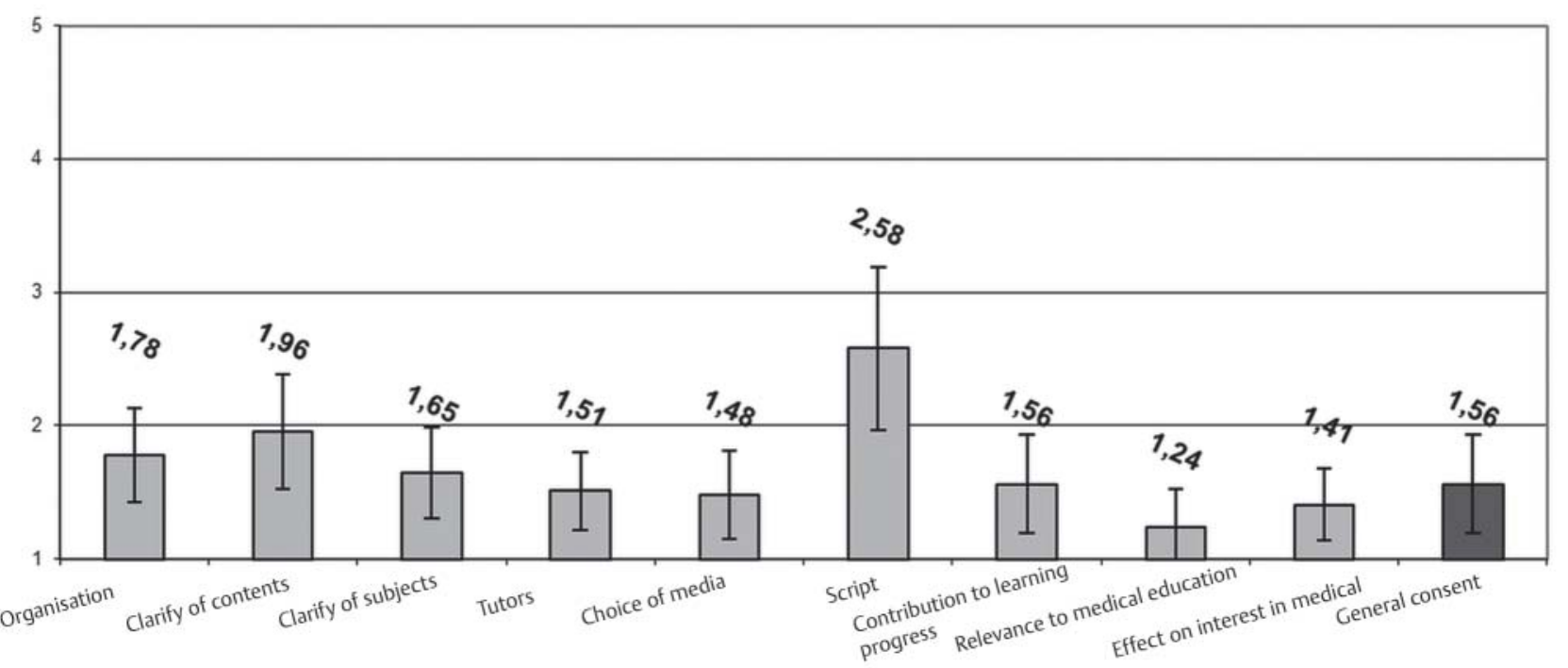

Fig. 2 Evaluation results for advanced course 5-point Likert scale (1: fully agree, 5: do not agree). 


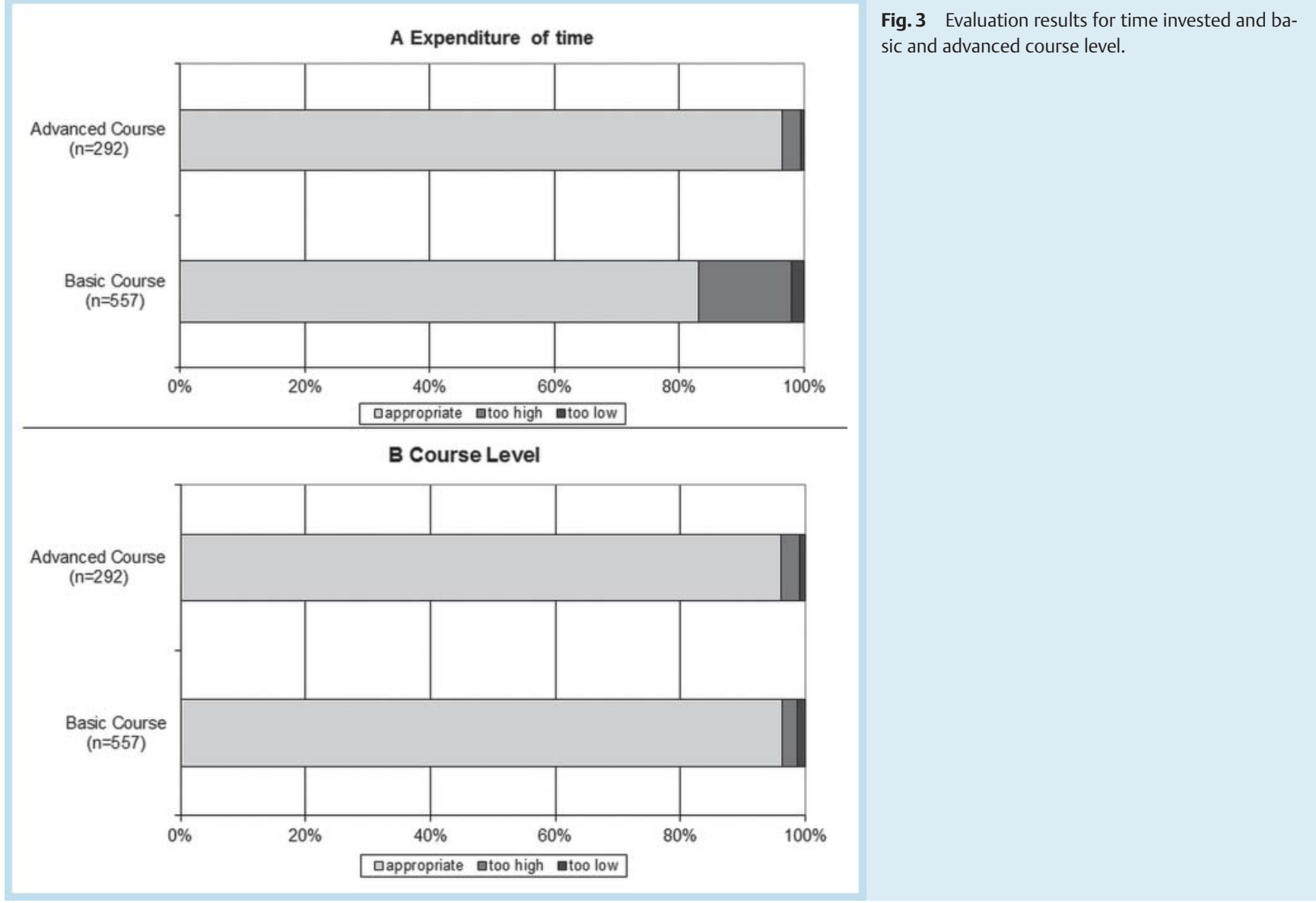

summarizing statement "I am satisfied with the course" received the rating 1.33 and 1.56 respectively on a ten-year average.

\section{Discussion}

The increase in medical knowledge confronts teaching in medical faculties with new challenges [20]. With the introduction of the new Licensing Regulations for Physicians (Approbationsordnung of 27/6/2002) in 2003, basic medical training in Germany was faced with new demands. These included a stronger link between preclinical theory and clinical knowledge, a stronger interdisciplinary, subject-focused learning method as well as new forms of examination and continuous evaluation of the teaching system [21]. Thereby anatomy teaching is also a hot topic of discussion. Various concepts have been developed in order to improve the quality [16].

A recent article once again called for the modernization of anatomy teaching at German faculties, demanding a closer liaison with clinical subjects. Dissecting exercises were questioned. One should focus on the anatomy of the living [9].

The use of imaging processes to improve visualization of anatomical relationships is a recommended possibility to obtain anatomical knowledge and to connect preclinical with clinical subject matter [22]. A simultaneous application of dissection, radiological film material, clinical cases and the achieving of clinical skills lead to a significant im- provement of the understanding of anatomy [23, 24]. According to a survey, $80 \%$ of students would welcome the introduction of imaging courses within the framework of teaching anatomy [16]. Also, the introduction of sonography courses has led to positive experiences with high rates of acceptance among students and a positive influence on the interest of anatomical knowledge [17 - 19].

The transmission of information into long-term memory and the rapid recall in a clinical situation depend crucially on the conditions under which the information was learned. Chiefly, active involvement, a connection with present knowledge, the obtaining of knowledge in similar situations like the recalling of knowledge, clear clinical relevance and a high rate of repetition are favorable to learning [4].

"Anatomy and Imaging" as a bridging course between preclinical and clinical semesters achieved the outlined goals by providing students with the means of repetition after their successful completion of the gross anatomy course, with facts and clinical radiological cases in a problemoriented setting. It is well known that the interactive form of a course as well as practical applications support the learning process [25].

The success of this concept is reflected in the results of the evaluation. The students of the basic and advanced courses rated almost all the statements with 1 to 2 . With a participation of over $90 \%$, this can be considered representative. The clinical relevance of the obtained correlation was noticeable, as the very good correlation results with 1.17 and 1.24 , respectively, demonstrate. 
Only the presented learning material of the advanced course was graded with 2.58 . The reasons for this most likely were the lack of illustration of the individual cases of the patients in the sonography lessons, and the omission of the synoptic cases in the third part of the course. These synoptic cases had been left out on purpose, so that the correct diagnosis could not be anticipated.

The course level was considered appropriate by almost all the students (more than 95\%). The amount of time used in the basic course was considered too much by $15 \%$ of the students. This could be explained by the fact that in the early years only half of the time spent in the course was recognized for the performance certificate. From 2006 onwards, the course was finally recognized as an elective course with graded certificates of 4 periods per week during the semester.

In addition, the question of efficacy of a preclinical imaging course for further education must be discussed.

A total of two-thirds of all graduates at seven German medical faculties feel badly prepared for their clinical work. Interpreting X-rays already ranks fifth among all deficiencies [26]. Taking a chest X-ray course as an example, the primary benefit lay less in the memorization of facts but rather in the alleviation of later repetition and intensification of the material from previous experiences [27]. Furthermore, a systematic analysis of a chest X-ray in an early study phase has the potential to create a reliable basis for the later daily working routine [28].

Because of its vital clinical significance, special emphasis was placed on the chest X-ray in our course as well. Conveying a systematic and reliable method for image interpretation was especially important.

"Anatomy and Imaging" is set up as a small group study in order to encourage active and practical work for students. A much discussed problem of this teaching method is the large amount of workload and use of personnel which leads to excessive costs and as a rule can hardly be carried out by qualified medical people.

A solution to the problem - in spite of uttered reservations [29] - could be the use of specially trained student tutors under the supervision of qualified medical personnel.

Comparing professional and student tutors by questioning participants of a pharmacology course, it became evident that neither specialized competence nor teaching experience had any significant influence on the students' results in the written final examinations [30]. Positive experiences were also reported regarding the student tutor system in the area of ultrasound courses $[17,18]$.

In the above course, the quality of the tutors was assessed by the participants with 1.42 and 1.51 , respectively. This shows the high acceptance of tutors in small group study. It must be noted that the tutors also expressed satisfaction with the demanding requirements which resulted in the fact that the majority stayed for many further semesters. It was also advantageous for the medical tutors. Maximum flexibility with respect to time planning was reached because of prearranged meetings with the well-trained student tutors. A meeting between instructors and tutors together at the end of the semester has proven to be very helpful. Evaluation results were assessed together and the following course was planned.
A difficulty of problem-oriented learning is that students can develop a special interest in the clinical background and then neglect their achieved basic knowledge [4]. An important task for the tutors of "Anatomy and Imaging" therefore was to maintain a systematic priority with image analysis and image interpretation.

The total positive resonance and the high number of applicants for the limited number of places indicated that an enlargement of the course concept would be desirable. For that reason, the basic course of 'Anatomy and Imaging' was enlarged as a block course for the winter semester 2012/ 2013 for a complete semester cohort, with 98 voluntary applications.

Following a decision by the local medical faculty, the course "Anatomy and Imaging" is now, since 2013, part of the curriculum for the third preclinical semester as a "seminar with clinical reference".

For radiology, the chance exists that students could be brought closer to this subject already in the preclinical stage and to develop an early interest in imaging.

- The implementation of modern clinical imaging techniques into the preclinical phase of medical studies represents a successful concept.

- „Anatomy and Imaging“ in undergraduate medical education creates a win-win situation: For the students to achieve relevant anatomical knowledge in a clinical context; for the radiologists to prime future clinicians for their field.

\section{Acknowledgements}

$\nabla$

The authors wish to thank Univ.-Prof. Walter Heindel, M. D. (Head of the Department of Clinical Radiology, University Hospital Muenster, Germany) and Univ.-Prof. Markus Missler, M.D. (Head of the Institute of Anatomy and Molecular Neurobiology, University of Muenster, Germany), as well as Bernhard Marschall, M. D. and Jan C. Becker, M. D. (Heads of the Department of Medical Education, Medical Faculty, University of Muenster, Germany) for their longstanding support. We would also like to thank the former leaders of the advanced course "Anatomy and Imaging”, Prof. Stefan Diederich M.D. (Head of the Institute of Radiology, Marien Hospital Dusseldorf), Dag Wormanns, M. D. (Head of the Radiological Institute of the Evangelische Lungenklinik Berlin) and Prof. Johannes Wessling, M. D. (Head of the Department of Radiology, Clemenshospital Muenster, Germany).

\section{Literatur}

1 Strate J, Rothkötter HJ, Pabst R. Wie beurteilen Medizinstudierende das vorklinische Studium? Ergebnisse von Befragungen nach dem 1. und 2. Studienjahr. Dtsch Med Wochenschr 1998; 123: 1093 - 1096

2 Hofer M, Jansen $M$, Soboll S. Verbesserungspotenzial des Medizinstudiums aus retrospektiver Sicht von Facharztprüflingen. Dtsch Med Wochenschr 2006; 131: $373-378$

3 Waterston SW, Stewart IJ. Survey of clinicians' attitudes to the anatomical teaching and knowledge of medical students. Clin Anat 2005; 18: $380-384$

4 Bergman EM, Prince KJ, Drukker J et al. How much anatomy is enough? Anat Sci Educ 2008; 1: $184-188$

5 Insull PJ, Kejriwal R, Blyth P. Surgical inclination and anatomy teaching at the University of Auckland. ANZ J Surg 2006; 76: 1056-1059 
6 Lippert $H$. Medizinstudium: Sind Präparierübungen an der Leiche noch zeitgemäß? Dtsch Arztebl 2012; 109: A-1758/B-1422/C-1401

7 Rengier F, Doll S, von Tengg-Kobligk $\mathrm{H}$ et al. Integrated teaching of anatomy and radiology using three-dimensional image post-processing. Eur Radiol 2009; 19: 2870-2877

8 Miles KA. Diagnostic imaging in undergraduate medical education: an expanding role. Clin Radiol 2005; 60: $742-745$

9 de Barros N, Rodrigues CJ, Rodrigues AJ Jr et al. The value of teaching sectional anatomy to improve CT scan interpretation. Clin Anat 2001; 14: $36-41$

10 Ganske I, Su T, Loukas M et al. Teaching methods in anatomy courses in North American medical schools the role of radiology. Acad Radiol 2006; 13: 1038 -1046

11 Erkonen WE, Albanese MA, Smith WL et al. Gross anatomy instruction with diagnostic images. Invest Radiol 1990; 25: 292-294

12 Erkonen WE, Albanese MA, Smith WL et al. Effectiveness of teaching radiologic image interpretation in gross anatomy. A long-term followup. Invest Radiol 1992; 27: 264-266

13 Pabst $R$, Westermann J, Lippert $H$. Integration of clinical problems in teaching gross anatomy: living anatomy, X-ray anatomy, patient presentations, and films depicting clinical problems. Anat Rec 1986; 215: $92-94$

14 Reeves RE, Aschenbrenner JE, Wordinger RJ et al. Improved dissection efficiency in the human gross anatomy laboratory by the integration of computers and modern technology. Clin Anat 2004; 17: 337-344

15 Turney BW. Anatomy in a modern medical curriculum. Ann R Coll Surg Engl 2007; 89: $104-107$

16 Rizzolo LJ, Stewart WB, O'Brien M et al. Design principles for developing an efficient clinical anatomy course. Med Teach 2006; 28: 142-151

17 Celebi N, Zwirner K, Lischner $U$ et al. Student tutors are able to teach basic sonographic anatomy effectively - a prospective randomized controlled trial. Ultraschall in Med 2012; 33: 141 - 145

18 Knobe M, Sellei RM, Maus U et al. Curriculare Ultraschallausbildung am Bewegungsapparat: Einfluss der anatomischen Vorbildung auf die Weitergabe von Basis-Skills an der Schulter. Z Orthop Unfall 2010; 148: $685-690$
19 Sugand K, Abrahams P, Khurana A. The anatomy of anatomy: a review for its modernization. Anat Sci Educ 2010; 3: 83-93

20 Dettmer S, Tschernig T, Galanski $M$ et al. Teaching surgery, radiology and anatomy together: the mix enhances motivation and comprehension. Surg Radiol Anat 2010; 32: 791 - 795

21 Chenot JF. Undergraduate medical education in Germany. Ger Med Sci 2009; 7: Doc02

22 Dettmer S, Schmiedl A, Meyer S et al. Radiological Anatomy - Evaluation of Integrative Education in Radiology. Fortschr Röntgenstr 2013; 185: $838-843$

23 Dusseau J, Knutson D, Way D. Anatomy correlations: introducing clinical skills to improve performance in anatomy. Fam Med 2008; 40: $633-637$

24 Navsa N, Boon JM, L'Abbé $L N$ et al. Evaluation of clinical relevance of a problem-orientated head and neck module. SADJ 2004; 59: 113-117

25 Löffler S, Feja C, Widmann J et al. Interaktives versus reproduktives Lernen. Absolventen medizinischer Berufsfachschulen im Vergleich zu Teilnehmern einer postgradualen Weiterbildung. GMS Z Med Ausbild $2011 ; 28(4)$

26 Ochsmann EB, Zier $U$, Drexler $H$ et al. Well prepared for work? Junior doctors' self-assessment after medical education. BMC Med Educ 2011; 11: 99

27 Feigin DS, Magid D, Smirniotopoulos JG et al. Learning and retaining normal radiographic chest anatomy: does preclinical exposure improve student performance? Acad Radiol 2007; 14: 1137-1142

28 Magid D, Hudson DW, Feigin DS. Chest radiographic anatomy retention: the impact of preclinical groundwork on clinical recall in two schools. Acad Radiol 2009; 16: 1443 - 1447

29 Grunewald M, Kuefner MA, Ketelsen D et al. Wie wir die Herausforderungen der neuen Approbationsordnung (AO) durch neue computergestützte radiologisch-interdisziplinäre Programme bewältigen können. Das Erlanger Modell. Radiologe 2007; 47: 1029-1036

30 Matthes J, Marxen B, Linke RM et al. The influence of tutor qualification on the process and outcome of learning in a problem-based course of basic medical pharmacology. Naunyn Schmiedebergs Arch Pharmacol 2002; 366: 58-63 